\title{
A gestão no âmbito do Sistema Único de Saúde: concepções e práticas de gestores municipais de saúde
}

\author{
Adélia Contiliano Expedito, Ariana Colombari de Godoi Floresta, Vanessa de Souza Amaral, \\ Amanda Medeiros Rodrigues, Ramon Augusto Ferreira Souza, Deíse Moura de Oliveira
}

\begin{abstract}
Resumo
Para que o Sistema Único de Saúde (SUS) se consolide nas diferentes realidades inscritas no território nacional faz-se necessário que o mesmo esteja sob a égide de uma gestão que compreenda o seu papel na construção do sistema, e que seja capaz de enfrentar e superar as contradições que permeiam a administração pública, com vistas a atender as necessidades de saúde da população. Analisar os saberes e práticas dos gestores municipais de saúde de uma microrregião de Minas Gerais com relação à gestão no âmbito do SUS. Pesquisa qualitativa, cujos participantes foram os gestores municipais de saúde de uma microrregião de Minas Gerais. A coleta de dados se deu nos meses de agosto e setembro de 2015, por meio de um roteiro de entrevista com questões abertas, realizada individualmente com cada secretário de saúde. Os dados foram analisados por meio da técnica de análise de conteúdo de Bardin e em consonância com a literatura pertinente à temática. $\mathrm{O}$ projeto o projeto foi aprovado pelo Comitê de Ética em Pesquisa com Seres Humanos da Universidade Federal de Viçosa, inscrito sob o Parecer $n^{\circ} 1.147 .443$, de 08 de julho de 2015. Os gestores demarcaram como funções do cargo o planejamento, a coordenação e a operacionalização de ações voltadas para a saúde no município em que atuam, e afirmam que precisam estar próximos dos trabalhadores da saúde e da comunidade. Apontaram como um dos maiores limites enfrentados na gestão da saúde o subfinanciamento do sistema e sinalizam a dificuldade que vivenciam com o repasse de recursos previstos pela União e Estado, que comumente ficam aquém do preconizado no acordo interfederativo, exigindo que o município arque com compromissos financeiros que não tem condições de assumir. Somado a isso apontam a morosidade e a burocracia do sistema como um desafio para a gestão, dificultando a implementação de projetos em tempo hábil. A questão da fragilização do vínculo e a ausência de perfil/competência do profissional para atuar no contexto do SUS, com destaque para os médicos alocados na Estratégia Saúde da Família, também se desdobra em um desafio para os gestores. Como potencialidades no desempenho das funções os gestores destacaram o apoio do prefeito, a cobertura total da atenção primária em alguns municípios, e também o conhecimento/experiência prévia do setor saúde. Para a melhoria da gestão municipal foi elencado como prioridade a necessidade de investimento na Atenção Primária à Saúde, considerada lócus potencial para as ações de prevenção e promoção da saúde. O presente estudo evidencia que os saberes e práticas dos gestores municipais é permeado por desafios, os quais estão relacionados ao perfil profissional do gestor e também ao modo como o sistema de saúde se efetiva na prática, marcado por contradições que precisam ser equacionadas para a consolidação do SUS.
\end{abstract}

Descritores: Sistema Único de Saúde; Gestão em Saúde; Pesquisa Qualitativa. 